\title{
ANALISIS PEMILIHAN PAKET LAYANAN INTERNET MENGGUNAKAN METODE ANALYTICAL HIERARCHY PROCESS DAN SIMPLE ADDITIVE WEIGHTING
}

\author{
Filipa Stephani Medyati, Marisi Aritonang, Setyo Wira Rizki
}

\begin{abstract}
INTISARI
Banyaknya paket internet yang ditawarkan oleh operator telekomunikasi, membuat pelanggan sulit untuk menentukan pilihan. Dengan demikian, adanya sebuah sistem pendukung keputusan pemilihan paket layanan internet diharapkan dapat membantu pengambilan keputusan untuk memilih paket layanan internet yang diinginkan atau yang dibutuhkan. Proses pemilihan paket internet ini merupakan permasalahan yang melibatkan banyak komponen atau kriteria yang dinilai (multikriteria), sehingga dalam penyelesaiannya diperlukan sebuah sistem pendukung keputusan dengan multikriteria. Metode sistem pendukung keputusan yang multikriteria antara lain adalah metode Analytical Hierarchy Process (AHP) dan metode Simple Additive Weighting (SAW). Metode SAW digunakan karena proses perhitungannya yang lebih mudah dipahami, cepat dan sederhana, sedangkan metode AHP lebih unggul dalam keakuratan data karena dalam menentukan nilai bobot kriteria dilakukan berdasarkan perhitungan. Dalam penelitian ini menerapkan metode snowball atau bola salju sebagai metode pengambilan sampel dengan teknik pengambilan sampel berdasarkan wawancara dan korespondensi. Pada penelitian ini terdapat empat operator telekomunikasi sebagai alternatif yaitu Telkomsel, Tri, Indosat, XL dan tiga kriteria yang digunakan, yaitu kriteria harga paket internet, kualitas jaringan internet dan layanan kartu operator. Hasil analisis dari kedua metode didapatkan alternatif terbaik adalah kartu XL.
\end{abstract}

Kata Kunci : Paket Internet, AHP, SAW, snowball

\section{PENDAHULUAN}

Di zaman yang serba cepat dengan perkembangan teknologi yang begitu pesat menuntut manusia untuk memiliki kemampuan dan kecerdasan dalam menggunakan teknologi-teknologi yang tersedia guna membantu memudahkan pekerjaan, mengakses informasi, menjalin komunikasi dan mempelajari hal baru. Teknologi yang tersedia sekarang ini sebagian besar sudah terkoneksi langsung dengan internet. Internet adalah suatu media yang digunakan untuk mengefisiensikan sebuah proses komunikasi yang dihubungkan dengan berbagai aplikasi seperti Web, VoIP, E-mail.

Kebutuhan akan koneksi internet semakin hari semakin meningkat seiring dengan tingginya kebutuhan manusia akan informasi dan komunikasi yang diperoleh dengan menggunakan internet. Pengguna internet tidak hanya didominasi oleh orang dewasa, melainkan sudah menjangkau semua usia mulai dari masyarakat yang tinggal di perkotaan hingga ke masyarakat yang tinggal di daerah-daerah di Indonesia. Adanya jasa penyedia layanan internet merupakan sebuah solusi untuk memenuhi kebutuhan terhadap layanan internet. Beberapa operator menawarkan kuota dengan paket yang sudah disesuaikan 
dengan durasi pemakaian selama satu bulan dengan selisih harga yang tidak terlalu jauh. Dengan beragam paket yang di tawarkan oleh operator telekomunikasi maka pengguna layanan internet harus dapat memilih paket internet yang sesuai dengan kebutuhan. Pemilihan paket layanan internet terbaik sesuai dengan kebutuhan merupakan permasalahan yang dihadapi oleh masyarakat secara luas yang melibatkan banyak komponen atau kriteria yang dinilai (multikriteria), sehingga dalam penyelesaiannya diperlukan sebuah sistem pendukung keputusan yang multikriteria.

Tujuan dari penelitian ini adalah menentukan pilihan terbaik pada setiap tingkatan hirarki yaitu pada tingkatan kriteria, subkriteria dan alternetif sesuai dengan keinginan atau kebutuhan dengan menggunakan metode AHP dan SAW. Metode pengambilan sampel yang digunakan peneliti dalam penelitian ini adalah metode snowball atau bola salju dengan teknik pengambilan sampel berdasarkan wawancara dan korespondensi. Metode snowball ini cocok untuk penelitian mengenai hal-hal yang bersifat sensitif dan membutuhkan privasi tinggi. Kriteria yang digunakan adalah harga paket internet, kualitas jaringan internet dan layanan kartu operator. Selanjutnya adalah menentukan subkriteria, subkriteria untuk kriteria harga paket internet adalah voucer internet, kuota internet elektrik dan kartu perdana. Subkriteria untuk kualitas jaringan internet adalah kualitas sinyal internet, kecepatan download, kecepatan upload, searching. Subkriteria untuk kriteria layanan kartu operator adalah call center, costumer service, bonus nelpon, bonus sms dan bonus internet. Selanjutnya adalah menentukan alternatif yang digunakan yaitu Telkomsel, Tri, Indosat dan XL. Dalam penelitian ini batasan masalah terletak pada jumlah kriteria, subkriteria dan alternatif yang digunakan.

\section{METODE AHP}

Metode Analytical Hierarchy Process (AHP) adalah sebuah metode pendukung pengambilan keputusan yang dikembangkan oleh Thomas L. Saaty pada untuk pemberian prioritas beberapa alternatif ketika beberapa kriteria harus dipertimbangkan, serta mengijinkan pengambil keputusan untuk menyusun masalah yang kompleks ke dalam suatu bentuk hirarki atau serangkaian level yang terintegrasi.

Model pendukung keputusan ini menguraikan masalah multifaktor atau multikriteria yang kompleks menjadi suatu hirarki yang dimulai dari level pertama adalah tujuan, yang diikuti level kriteria, subkriteria hingga ke level alternatif. Dengan adanya struktur hirarki suatu permasalahan yang kompleks akan tampak lebih terstruktur dan sistematis.

langkah-langkah dalam metode AHP adalah sebagai berikut [1] :

1. Membuat matriks perbandingan berpasangan sebagai berikut :

$$
A=\left[a_{i j}\right]=\left(\begin{array}{cccc}
1 & a_{12} & \cdots & a_{1 n} \\
\frac{1}{a_{12}} & 1 & \cdots & a_{2 n} \\
\vdots & \vdots & \cdots & \vdots \\
\frac{1}{a_{m 1}} & \frac{1}{a_{m 2}} & \cdots & 1
\end{array}\right)
$$


Misalkan $A_{i}$ dan $A_{j}$ adalah elemen ke-i dan ke-j berturut-turut yang akan dibandingkan. Nilai perbandingan elemen $A_{i}$ terhadap elemen $A_{j}$ adalah $\mathrm{a}_{\mathrm{ij}}$. Matriks perbandingan berpasangan hanya mengisi nilai dari segitiga atas dan diagonal utamanya. Nilai pada diagonal utama selalu bernilai 1 karena perbandingan kriteria a dengan kriteria a hasilnya 1. Untuk mengisi nilai segitiga atas, digunakan perbandingan intensitas kepentingan dengan berdasarkan Tabel 1. Penilaian perbandingan paling baik adalah menggunakan skala 1 sampai dengan 9, dimana $\left(\mathrm{a}_{\mathrm{ij}}\right) ; \mathrm{i}, \mathrm{j}=1,2, \ldots, n$. Matriks $A$ berciri positif resiprokal (berkebalikan), yakni $\mathrm{a}_{\mathrm{ij}}=\frac{1}{\mathrm{a}_{\mathrm{ji}}}$ diatas disebut matriks tingkat $\mathrm{mxn}$, yang terdiri dari $m$ adalah baris dan $n$ adalah kolom. Setiap $\mathrm{a}_{\mathrm{ij}}$ disebut elemen atau unsur dari matriks tersebut, sedang indeks $\mathrm{i}$ dan $\mathrm{j}$ berturut-turut menyatakan baris dan kolom. Pasangan bilangan ( $\mathrm{m}, \mathrm{n}$ ) disebut dimensi (ukuran dan bentuk) dari matriks tersebut.

Tabel 1 Skala intensitas kepentingan pada matriks pairwise comparison [2]

\begin{tabular}{cll}
\hline Intensitas Kepentingan & \multicolumn{1}{c}{ Definisi } & \multicolumn{1}{c}{ Keterangan } \\
\hline 1 & Sama penting & Kedua kriteria sama penting. \\
\hline 3 & $\begin{array}{l}\text { Sedikit lebih } \\
\text { penting }\end{array}$ & $\begin{array}{l}\text { Kriteria yang satu sedikit lebih penting daripada kriteria } \\
\text { lainnya. }\end{array}$ \\
\hline 5 & Lebih penting & Kriteria yang satu lebih penting daripada kriteria lainnya. \\
\hline 7 & $\begin{array}{l}\text { Sangat lebih } \\
\text { penting }\end{array}$ & $\begin{array}{l}\text { Kriteria yang satu jelas lebih mutlak penting daripada } \\
\text { kriteria lainnya. }\end{array}$ \\
\hline $2,4,6,8$ & $\begin{array}{l}\text { Mutlak lebih } \\
\text { penting }\end{array}$ & Kriteria yang satu mutlak penting daripada kriteria lainnya. \\
\hline Kebalikan & $\begin{array}{l}\text { Nilai-nilai di antara dua nilai pertimbangan kriteria yang } \\
\text { berdekatan. }\end{array}$ \\
\hline
\end{tabular}

2. Menormalisasi matriks keputusan dilakukan dengan membagi nilai dari setiap elemen pada matriks perbandingan berpasangan dengan nilai total dari setiap kolom dengan rumus sebagai berikut :

$$
c_{i j}=\frac{a_{i j}}{P_{j}},
$$

dimana

$c_{i j}=$ Normalisasi nilai rata-rata geometrik perbandingan berpasangan kriteria $A_{i}$ dengan $A_{j}$

$P_{j}=$ Jumlahan nilai dari tiap kolom pada matriks

3. Menentukan bobot kriteria dengan cara merata-ratakan nilai tiap baris matriks. Bobot yang dicari dinyatakan dalam vektor $=\left(w_{1}, w_{2}, \ldots, w_{n}\right)$. Nilai $w_{n}$ menyatakan nilai bobot.

$$
w_{n}=\frac{1}{n} \sum_{j=1}^{n} a_{i j}
$$

4. Menentukan tingkat konsistensi dari matriks perbandingan berpasangan yang telah didapat dari langkah sebelumnya. Langkah-langkahnya sebagai berikut :

a. Menentukan $\lambda_{1}, \lambda_{2}, \ldots, \lambda_{\mathrm{n}}$ yang didapat dengan cara mengalikan bobot setiap kriteria dengan jumlah kolom matriks keputusan pada langkah 2 .

b. Menentukan nilai $\lambda_{\text {maks }}$ dengan langkah $\lambda_{\text {maks }}=\frac{\lambda_{1}+\lambda_{2}+\ldots+\lambda_{n}}{n}$. 
Nilai $\lambda_{\text {maks }}$ merupakan nilai eigen terbesar dari matriks.

c. Menghitung Consistency Index (CI) sebagai berikut.

$$
C I=\frac{\lambda_{\mathrm{maks}}-\mathrm{n}}{\mathrm{n}-1}
$$

dengan $n$ adalah banyaknya kriteria.

d. Menghitung Consistency Ratio (CR) sebagai berikut.

$$
C R=\frac{C I}{R I},
$$

dengan RI adalah Random Consistency Index yang ditunjukkan oleh Tabel 2 berikut [3] :

Tabel 2 Tabel Random Consistency Index (RI)

\begin{tabular}{ccccccccccc}
\hline Ukuran matriks & 1 & 2 & 3 & 4 & 5 & 6 & 7 & 8 & 9 & 10 \\
\hline RI & 0,00 & 0,00 & 0,52 & 0,89 & 1,11 & 1,25 & 1,35 & 1,40 & 1,45 & 1,49 \\
\hline
\end{tabular}

Jika nilai $C R \leq 0,10$ artinya matriks perbandingan berpasangan dapat dikatakan konsisten dan bobot yang dihasilkan dapat digunakan untuk perankingan alternatif dengan metode SAW pada langkah selanjutnya.

\section{METODE SAW}

Metode SAW merupakan metode penjumlahan terbobot. Konsep dasar metode SAW adalah mencari penjumlahan terbobot dari rating kinerja setiap alternatif pada semua kriteria. Metode SAW membutuhkan proses normalisasi matriks keputusan $(X)$ ke suatu skala yang dapat diperbandingkan dengan semua rating alternatif yang ada.

Metode ini mengharuskan pembuat keputusan menentukan bobot bagi setiap atribut. Skor total untuk sebuah alternatif yaitu diperoleh dengan menjumlahkan seluruh hasil perkalian antar rating dan bobot tiap atribut. Rating tiap atribut haruslah bebas dimensi dalam arti telah melewati proses normalisasi sebelumnya.

Langkah-langkah dalam metode Simple Additive Weigthting (SAW) ialah sebagai berikut [4] :

1. Menentukan kriteria-kriteria yang akan dijadikan acuan dalam pengambilan keputusan, yaitu $C_{i}$

2. Menentukan rating kecocokan setiap alternatif pada setiap kriteria.

3. Membuat matriks keputusan berdasarkan kriteria $\left(C_{i}\right)$, kemudian melakukan normalisasi matriks berdasarkan persamaan yang disesuaikan dengan jenis atribut (atribut keuntungan ataupun atribut biaya) sehingga diperoleh matriks ternomalisasi $\tilde{R}$.

4. Hasil akhir diperoleh dari proses pengurutan yaitu penjumlahan dari perkalian matriks ternormalisasi $\tilde{R}$ dengan vektor bobot sehingga diperoleh nilai terbesar yang dipilih sebagai alternatif terbaik $\left(A_{i}\right)$ sebagai solusi.

Rumus untuk melakukan normalisasi tersebut adalah :

$$
\widetilde{R}_{\mathrm{ij}}=\left\{\begin{array}{c}
\frac{\mathrm{x}_{\mathrm{ij}}}{\operatorname{maxx}_{\mathrm{ij}}}, \mathrm{jika} \mathrm{j} \text { adalah keuntungan (benefit) } \\
\frac{\operatorname{minx}_{\mathrm{ij}}}{\mathrm{x}_{\mathrm{ij}}}, \mathrm{jika} \mathrm{j} \text { adalah biaya (cost) }
\end{array}\right.
$$


dengan

$x_{i j}=$ Rating kinerja normalisasi dari alternatif pada atribut $C ; \mathrm{i}=1,2, \ldots, \mathrm{n}$

$\tilde{R}_{i j} \quad=$ nilai rating kinerja normalisasi

$\max x_{i j}=$ nilai terbesar dari setiap kriteria

$\min x_{i j}=$ nilai terkecil dari setiap kriteria

Nilai preferensi untuk setiap alternatif $\left(V_{i}\right)$ ialah sebagai berikut :

$$
V_{i}=\sum_{j=1}^{n} w_{j} r_{i j}
$$

dengan

$V_{i}=$ urutan untuk setiap alternatif

$w_{j}=$ nilai bobot dari setiap kriteria

$r_{i j}=$ nilai rating kinerja ternormalisasi

Nilai $V_{i}$ yang lebih besar mengindikasikan bahwa alternatif lebih dipilih.

\section{PENGUMPULAN DATA}

Data pada penelitian ini adalah data primer yang diperoleh dari jawaban responden pada kuesioner yang telah disebar oleh peneliti. Kuesioner tersebut berisi kriteria, subkriteria dan alternatif yang dibuat berdasarkan keperluan penelitian dengan tujuan pemilihan paket layanan internet terbaik dari empat operator telekomunikasi terpilih yaitu Telkomsel, Tri, Indosat dan XL. Keempat operator telekomunikasi tersebut dipilih karena banyak digunakan oleh mahasiswa.

Responden pada penelitian ini adalah 30 orang mahasiswa pengguna internet. Pernah menggunakan kartu operator yang berbeda-beda atau mengetahui informasi mengenai keempat kartu operator terpilih tersebut. Metode pengambilan sampel yang digunakan peneliti dalam penelitian ini adalah metode snowball atau bola salju dengan teknik pengambilan sampel berdasarkan wawancara dan korespondensi. Metode ini cocok untuk penelitian mengenai hal-hal yang bersifat sensitif dan membutuhkan privasi tinggi.

\section{PERHITUNGAN METODE AHP}

Analisis metode AHP menggunakan langkah-langkah pengerjaan berdasarkan prinsip-prinsip dasar pengerjaan metode AHP seperti berikut ini [5] :

1. Penyusunan Hirarki

Penyusunan hirarki dilakukan jika permasalahan telah didefinisikan. Dari permasalahan tersebut kemudian dipecah atau dibagi menjadi berbagai level atau tingkatan. Pemecahan dilakukan hingga tidak mungkin lagi dilakukan pemecahan lebih lanjut untuk mendapatkan hasil yang akurat. Dalam metode AHP, elemen yang terdapat didalam suatu permasalahan biasanya disusun kedalam suatu bentuk hirarki. Elemen tersebut dapat berupa kriteria, subkriteria dan alternatif. 


\section{Menentukan Prioritas Elemen}

Langkah-langkah menentukan prioritas elemen sebagai berikut :

a. Matriks perbandingan berpasangan menggambarkan pengaruh setiap elemen terhadap masingmasing tujuan atau kriteria yang setingkat di atasnya. Perbandingan dilakukan berdasarkan pada pilihan dari pembuat keputusan dengan menilai tingkat kepentingan suatu elemen yang dibandingkan dengan elemen lainnya. Agar diperoleh bobot penilaian dari masing-masing elemen maka dibuat tabel skala penilaian perbandingan berpasangan. Data untuk pengukuran prioritas kepentingan diperoleh melalui kuesioner yang dibagikan kepada 30 orang mahasiswa yang menggunakan internet dalam kehidupan sehari-hari mereka.

b. Menghitung rata-rata geometrik

Setelah mendapatkan penilaian, kemudian dihitung rata-rata dari setiap elemen pada hirarki menggunakan rata-rata geometrik. Perhitungan rata-rata geometrik dilakukan karena pada metode AHP hanya memerlukan satu jawaban untuk melakukan perhitungan pada matriks perbandingan berpasangan.

3. Sintesis Dan Uji Konsistensi

Langkah-langkah dalam mensintesis dan menguji konsistensi sebagai berikut :

1 Menghitung bobot kepentingan dari setiap elemen pada level satu atau level kriteria yaitu harga paket internet, kualitas jaringan internet dan layanan kartu operator. Sesuai dengan landasan aksiomatik AHP yang mempunyai sifat berkebalikan sehingga pada $a_{12}$ responden 1 memberikan nilai 7 maka pada $a_{21}$ untuk responden 1 mendapatkan nilai $\frac{1}{7}$ atau 0,14 . Responden 2 memberikan nilai 1 untuk $a_{12}$ maka pada $a_{21}$ untuk responden 2 mendapat nilai 1 . Responden 3 memberikan nilai 1 untuk $a_{12}$ maka nilai untuk $a_{21}$ responden 3 memberikan nilai 1 dan seterusnya hingga responden ke 30 seperti berikut :

$$
\begin{aligned}
& a_{12}=(9 \times 0,33 \times 1 \times 9 \times 1 \times 9 \times 1 \times \ldots \times 0,14 \times 7 \times \ldots \times 9)^{\frac{1}{30}} \\
& a_{21}=(0,11 \times 3 \times 1 \times 0,11 \times 1 \times 0,11 \times \ldots \times 1 \times 7 \times 0,14 \times \ldots \times 0,11)^{\frac{1}{30}}
\end{aligned}
$$

Tabel 3 Matriks perbandingan berpasangan

\begin{tabular}{lccc}
\hline \multicolumn{1}{c}{ Kriteria } & $\begin{array}{c}\text { Harga Paket } \\
\text { Internet }\end{array}$ & $\begin{array}{c}\text { Kualitas } \\
\text { Layanan Internet }\end{array}$ & $\begin{array}{c}\text { Layanan Kartu } \\
\text { Operator }\end{array}$ \\
\hline Harga Paket Internet & 1,00 & 3,69 & 0,24 \\
\hline Kualitas Layanan Internet & 0,27 & 1,00 & 0,15 \\
\hline Layanan Kartu Operator & 4,14 & 6,54 & 1,00 \\
\hline Jumlah & 5,41 & 11,23 & 1,39 \\
\hline
\end{tabular}

Berdasarkan Tabel 3 diperoleh nilai dari matriks perbandingan berpasangan pada masing-masing kriteria yaitu kriteria harga paket internet, kriteria kualitas jaringan internet dan kriteria layanan kartu operator. Langkah selanjutnya menghitung nilai eigen dan vektor eigen dengan cara normalisasi matriks, yaitu unsur-unsur pada tiap kolom yang bersangkutan, akan diperoleh bobot relatif yang dinormalkan. Nilai vektor eigen yang dinormalkan dihasilkan dari rata-rata bobot relatif untuk setiap baris. 
Hasil dari nilai vektor yang dinormalisasikan dapat dilihat pada Tabel 4.

Tabel 4 Normalisasi matriks perbandingan berpasangan pada kriteria

\begin{tabular}{lcccc}
\hline \multicolumn{1}{c}{ Kriteria } & $\begin{array}{c}\text { Harga Paket } \\
\text { Internet }\end{array}$ & $\begin{array}{c}\text { Kualitas Layanan } \\
\text { Internet }\end{array}$ & $\begin{array}{c}\text { Layanan Kartu } \\
\text { Operator }\end{array}$ & Bobot \\
\hline Harga Paket Internet & 0,18 & 0,33 & 0,17 & 0,22 \\
\hline Kualitas Jaringan Internet & 0,05 & 0,09 & 0,11 & 0,08 \\
\hline Layanan Kartu Operator & 0,77 & 0,58 & 0,72 & 0,70 \\
\hline
\end{tabular}

Tabel 4 menunjukan bahwa pada kriteria, layanan kartu operator menempati prioritas utama terhadap paket layanan internet dibandingkan harga paket dan kualitas jaringan internet yaitu dengan bobot 0,70 . Nilai bobot tersebut harus diuji tingkat konsistensinya terlebih dahulu sebelum ditetapkan sebagai prioritas. Langkah selanjutnya adalah mengalikan nilai matriks pada Tabel 3 dengan nilai bobot pada Tabel 4 sehingga menghasilkan nilai sebagai berikut :

$$
A w=\left[\begin{array}{ccc}
1 & 3,69 & 0,24 \\
0,27 & 1 & 0,15 \\
4,14 & 6,54 & 1
\end{array}\right]\left[\begin{array}{l}
0,22 \\
0,08 \\
0,70
\end{array}\right]=\left[\begin{array}{l}
0,68 \\
0,24 \\
2,13
\end{array}\right]
$$

Langkah selanjutnya adalah menguji konsistensi vektor dengan cara membagi nilai tiap baris pada pada Persamaan (5) dengan nilai bobot pada Tabel 4 sehingga menghasilkan nilai sebagai berikut :

$$
\lambda_{\mathrm{i}}=\left[\begin{array}{l}
0,68 / 0,22 \\
0,24 / 0,08 \\
2,13 / 0,70
\end{array}\right]=\left[\begin{array}{l}
3,06 \\
3,10 \\
3,05
\end{array}\right]
$$

Nilai rata-rata dari entri vektor pada Persamaan (6) merupakan nilai eigen maksimal.

$$
\lambda_{\text {maks }}=3,07,
$$

Setelah mendapatkan nilai $\lambda_{\text {maks }}$ langkah selanjutnya adalah menghitung nilai indeks konsistensi.

$$
C I=\frac{\lambda_{\text {maks }}-\mathrm{n}}{\mathrm{n}-1}=0,03,
$$

Untuk $n=3$, pada Tabel 2 diperoleh nilai $R I=0,52$ maka diperoleh nilai rasio konsistensi seperti berikut:

$$
C R=\frac{C I}{R I}=0,07,
$$

Karena nilai $C R=0,07<0,10$ berarti penilaian responden konsisten dan bobot yang telah diperoleh dapat digunakan untuk penetapan prioritas. Dengan demikian diketahui bahwa responden pada umumnya berpendapat bahwa layanan kartu operator sangat berpengaruh untuk paket layanan internet.

\section{PERHITUNGAN METODE SAW}

Langkah-langkah dalam metode Simple Additive Weigthting (SAW) ialah sebagai berikut :

1. Menentukan kriteria-kriteria yang akan dijadikan acuan dalam pengambilan keputusan, yaitu $C_{i}$.

2. Menentukan rating kecocokan setiap alternatif pada setiap kriteria. 
3. Membuat matriks keputusan berdasarkan kriteria $\left(C_{i}\right)$ kemudian melakukan normalisasi matriks berdasarkan persamaan yang disesuaikan dengan jenis atribut (atribut keuntungan ataupun atribut biaya) sehingga diperoleh matriks normalisasi $\tilde{R}$.

4. Hasil akhir diperoleh dari proses pengurutan yaitu penjumlahan dari hasil perkalian matriks ternomalisasi $\tilde{R}$ dengan vektor bobot sehingga diperoleh nilai terbesar yang dipilih sebagai alternatif terbaik $\left(A_{i}\right)$ sebagai solusi.

Untuk membuat matriks keputusan berdasarkan kriteria, langkah yang dilakukan adalah menentukan terlebih dahulu nilai rata-rata atau bobot rating kecocokan dari 30 responden yang sudah terdata. Kemudian setelah selesai menentukan rating kecocokannya, maka nilai rata-rata keputusan atau bobot pada kriteria harga paket internet dapat dilihat pada Tabel 4.

Setelah menentukan matriks keputusan, selanjutnya dilakukan normalisasi matriks perbandingan berpasangan berdasarkan persamaan yang disesuaikan dengan jenis atribut (atribut keuntungan (benefi) dan atribut biaya (cost)), sehingga diperoleh matriks ternormalisasi $\tilde{R}$ sebagai berikut :

Untuk kriteria harga paket internet dikategorikan masuk kedalam atribut biaya (cost) karena semakin kecil nilainya semakin baik. Dalam artian bahwa semakin murah harga paket internet tersebut semakin banyak pembelinya.

$R_{11}=\frac{\min \{1,00 ; 0,27 ; 4,14\}}{1,00}=0,27$

Untuk kriteria kualitas jaringan internet dan layanan kartu operator dikategorikan masuk kedalam atribut keuntungan (benefit) karena semakin tinggi nilainya semakin baik. Dalam artian semakin baik kualitas jaringan internet yang di sediakan oleh sebuah operator telekomunikasi akan semakin banyak pengguna yang menggunakan kartu operator tersebut. Begitu juga dengan layanan kartu operator, semakin memuaskan pelayanan dari kartu operator tersebut maka akan semakin banyak pula pelanggan yang menggunakannya.

$R_{21}=\frac{0,27}{\max \{1,00 ; 0,27 ; 4,14\}}=0,06$
$R_{31}=\frac{4,14}{\max \{1,00 ; 0,27 ; 4,14\}}=1,00$

Tabel 5 Matriks ternormalisasi pada kriteria

\begin{tabular}{lccc}
\hline \multicolumn{1}{c}{ Kriteria } & $\begin{array}{c}\text { Harga Paket } \\
\text { Internet }\end{array}$ & $\begin{array}{c}\text { Kualitas Layanan } \\
\text { Internet }\end{array}$ & $\begin{array}{c}\text { Layanan Kartu } \\
\text { Operator }\end{array}$ \\
\hline Harga Paket Internet & 0,27 & 0,27 & 0,63 \\
\hline Kualitas Jaringan Internet & 0,06 & 0,15 & 0,15 \\
\hline Layanan Kartu Operator & 1,00 & 1,00 & 1,00 \\
\hline
\end{tabular}

5. Proses pengurutan atau perankingan yaitu penjumlahan dari perkalian matriks ternormalisasi $\tilde{R}$. Nilai terbesar yang diperoleh sebagai alternatif terbaik $\left(A_{i}\right)$ sebagai solusi. Pada langkah keempat ini, sebelum melakukan proses pengurutan atau perankingan ditentukan terlebih dahulu matriks $\widetilde{w}$. Matriks $\widetilde{w}$ adalah perkalian antara matriks ternormalisasi pada kriteria berdasarkan nilai atribut dengan nilai bobot kepentingan pada kriteria seperti pada Tabel 4. 
Tabel 6 Bobot prioritas dan ranking tertinggi pada setiap kriteria, subkriteria dan alternatif

\begin{tabular}{|c|c|c|c|c|c|c|c|}
\hline Kriteria & Subkriteria & Bobot & Ranking & Alternatif & Bobot & Ranking & $C R$ \\
\hline \multirow{12}{*}{$\begin{array}{c}\text { Harga } \\
\text { Paket } \\
\text { Internet } \\
(0,22) \\
(0,52)\end{array}$} & \multirow{4}{*}{$\begin{array}{l}\text { Voucher } \\
\text { Internet }\end{array}$} & \multirow{4}{*}{0,18} & \multirow{4}{*}{1,00} & Telkomsel & 0,43 & 0,25 & \multirow{4}{*}{0,05} \\
\hline & & & & Tri & 0,11 & 1,00 & \\
\hline & & & & Indosat & 0,26 & 0,52 & \\
\hline & & & & $\mathrm{XL}$ & 0,20 & 0,58 & \\
\hline & \multirow{4}{*}{$\begin{array}{c}\text { Kartu } \\
\text { Kuota } \\
\text { Elektrik }\end{array}$} & \multirow{4}{*}{0,52} & \multirow{4}{*}{0,34} & Telkomsel & 0,38 & 0,29 & \multirow{4}{*}{0,01} \\
\hline & & & & Tri & 0,11 & 0,96 & \\
\hline & & & & Indosat & 0,27 & 0,44 & \\
\hline & & & & XL & 0,23 & 0,58 & \\
\hline & \multirow{4}{*}{$\begin{array}{c}\text { Kartu } \\
\text { Perdana }\end{array}$} & \multirow{4}{*}{0,31} & \multirow{4}{*}{0,56} & Telkomsel & 0,38 & 0,29 & \multirow{4}{*}{0,00} \\
\hline & & & & Tri & 0,11 & 1,00 & \\
\hline & & & & Indosat & 0,30 & 0,39 & \\
\hline & & & & XL & 0,21 & 0,49 & \\
\hline \multirow{16}{*}{$\begin{array}{c}\text { Kualitas } \\
\text { Jaringan } \\
\text { Internet } \\
(0,08) \\
(0,13)\end{array}$} & \multirow{4}{*}{$\begin{array}{l}\text { Kualitas } \\
\text { Sinyal } \\
\text { Internet }\end{array}$} & \multirow{4}{*}{0,11} & \multirow{4}{*}{0,31} & Telkomsel & 0,07 & 0,19 & \multirow{4}{*}{0,05} \\
\hline & & & & Tri & 0,25 & 0,69 & \\
\hline & & & & Indosat & 0,34 & 0,91 & \\
\hline & & & & XL & 0,34 & 0,99 & \\
\hline & \multirow{4}{*}{$\begin{array}{l}\text { Kecepatan } \\
\text { Download }\end{array}$} & \multirow{4}{*}{0,27} & \multirow{4}{*}{0,66} & Telkomsel & 0,06 & 0,15 & \\
\hline & & & & Tri & 0,29 & 0,73 & \\
\hline & & & & Indosat & 0,38 & 1,00 & 0,03 \\
\hline & & & & $\mathrm{XL}$ & 0,27 & 0,73 & \\
\hline & & & & Telkomsel & 0,06 & 0,14 & \\
\hline & Kecepatan & 036 & & Tri & 0,27 & 0,65 & 001 \\
\hline & Upload & 0,36 & 0,91 & Indosat & 0,38 & 0,91 & 0,01 \\
\hline & & & & XL & 0,29 & 0,75 & \\
\hline & & & & Telkomsel & 0,06 & 0,14 & \\
\hline & Soambino & 026 & 068 & Tri & 0,20 & 0,42 & 001 \\
\hline & Searching & 0,20 & 0,08 & Indosat & 0,43 & 1,00 & 0,01 \\
\hline & & & & $\mathrm{XL}$ & 0,31 & 0,69 & \\
\hline & & & & Telkomsel & 0,14 & 0,39 & \\
\hline & Call & 030 & & Tri & 0,20 & 0,53 & \\
\hline & Center & 0,39 & 1,00 & Indosat & 0,21 & 0,86 & 0,01 \\
\hline & & & & XL & 0,36 & 1,01 & \\
\hline & & & & Telkomsel & 0,13 & 0,41 & \\
\hline & Costumer & 037 & 004 & Tri & 0,22 & 0,60 & \\
\hline & Service & 0,37 & 0,94 & Indosat & 0,27 & 0,75 & 0,01 \\
\hline & & & & XL & 0,36 & 1,00 & \\
\hline Layanan & & & & Telkomsel & 0,28 & 0,85 & \\
\hline Kartu & Bonus & 007 & (2) & Tri & 0,23 & 0,72 & \\
\hline $\begin{array}{l}\text { Uperator } \\
(070)\end{array}$ & Nelpon & 0,07 & 0,22 & Indosat & 0,20 & 0,59 & 0,04 \\
\hline$(0, / 0)$ & & & & XL & 0,30 & 0,88 & \\
\hline & & & & Telkomsel & 0,33 & 0,60 & \\
\hline & Bonus & 014 & 031 & Tri & 0,33 & 0,44 & 000 \\
\hline & SMS & 0,14 & 0,31 & Indosat & 0,20 & 0,63 & 0,00 \\
\hline & & & & XL & 0,14 & 0,94 & \\
\hline & & & & Telkomsel & 0,13 & 0,97 & \\
\hline & & 004 & & Tri & 0,53 & 0,25 & \\
\hline & Internet & 0,04 & 0,12 & Indosat & 0,15 & 0,65 & 0,04 \\
\hline & & & & XL & 0,19 & 0,65 & \\
\hline
\end{tabular}

Berdasarkan hasil perhitungan pada Tabel 6 diperoleh nilai untuk masing-masing kriteria, subkriteria dan alternatif. Untuk kriteria harga paket internet didapatkan kriteria terbaik adalah layanan kartu operator dengan nilai $(0,70)$ menggunakan metode AHP dan kriteria harga paket dengan nilai $(0,52)$ menggunakan metode SAW. Pada subkriteria voucher internet dilakukan perhitungan dengan 
menggunakan metode AHP mendapatkan alternatif terbaik yaitu kartu Telkomsel dengan nilai $(0,43)$ dan dengan menggunakan metode SAW ranking tertinggi berada pada kartu operator Tri dengan nilai $(1,00)$. Nilai-nilai tersebut bisa dijadikan solusi dengan syarat $C R \leq 0,10$, jika tidak maka penilaian perlu diulangi.

\section{KESIMPULAN}

Berdasarkan hasil analisis data yang dilakukan maka dapat diambil kesimpulan sebagai berikut :

1. Level kriteria, dengan menggunakan metode AHP kriteria yang diprioritaskan adalah layanan kartu operator dengan nilai $(0,70)$, dengan menggunakan metode SAW perankingan tertinggi ada pada kriteria layanan kartu operator dengan nilai $(1,00)$.

2. Level subkriteria, dengan menggunakan metode AHP subkriteria yang diprioritaskan pada masingmasing kriteria adalah kuota internet elektrik dengan nilai (0,52), kecepatan upload dengan nilai $(0,36)$, dan call center dengan nilai $(0,39)$. Dengan menggunakan metode SAW subkriteria dengan ranking tertinggi pada masing-masing kriteria adalah voucher internet dengan nilai $(1,00)$, kecepatan upload dengan nilai $(0,97)$ dan call center dengan nilai $(1,00)$.

3. Level alternatif, kartu XL merupakan pilihan prioritas dari responden diikuti dengan Telkomsel, Indosat, Tri dengan menggunakan metode AHP dan kartu XL menempati ranking tertinggi diikuti dengan Indosat, Tri, Telkomsel dengan menggunakan metode SAW.

\section{DAFTAR PUSTAKA}

[1] Saaty TL. Decision Making With The Analytical Hierarchy Process. Services Science. 2008. 1(1).

[2] Hafiyusholeh M, et al. Aplikasi Metode Nilai Eigen Dalam Analytical Hierarchy Process Untuk Memilih Tempat Kerja. Jurnal Matematika “MANTIK”. 2015;1(1).

[3] Saaty TL, Vargas LG. Models, Methods, Concepts, Applications of the Analytical Hierarchy Process. New York: Springer, 2001.

[4] Darmastuti D. Implementasi Metode Simple Additive Weighting dalam Sistem Informasi Lowongan Kerja Berbasis Web untuk Rekomendasi Pencari Kerja Terbaik, Jurnal Sistem dan Teknik Informasi. Fakultas Teknik Untan, Pontianak, 2013.

[5] Ardiansyah OM, Siregar K. Implementasi Sistem Pendukung Keputusan Pemilihan Siswa Berprestasi Menggunakan Metode Analytical Hierarchy Process (AHP) pada SMK Negeri 1 Rundeng. Pelita Informatika Budi Darma. 2016;15(1): 12-18.

FILIPA STEPHANI MEDYATI

MARISI ARITONANG

SETYO WIRA RIZKI
: FMIPA Untan Pontianak, filipastephani@gmail.com

: FAPERTA Untan Pontianak, marisi.hetty2018@gmail.com

: FMIPA Untan Pontianak, setyo.wirarizki@ math.untan.ac.id 